\title{
Performance of Rice Husk Ash as a Partial Cement Replacement in Fine Grained Mortar
}

\author{
Noor Shuhada Mohammad ${ }^{1, a^{*}}$, Suraya Hani Adnan ${ }^{2, b,}$ Zalipah Jamellodin ${ }^{1, c}$ \\ and Wan Yuslinda Wan Yusof ${ }^{1, d}$ \\ ${ }^{1}$ Faculty of Civil and Environmental Engineering, Universiti Tun Hussein Onn Malaysia, Batu \\ Pahat, Johor, Malaysia \\ ${ }^{2}$ Faculty of Engineering Technology, Universiti Tun Hussein Onn Malaysia, Batu Pahat, Johor \\ a shuhadamohammad89@gmail.com, b suraya@uthm.edu.my, ${ }^{c}$ zalipah@uthm.edu.my , \\ dyuslinda89@gmail.com
}

Keywords: rice husk ash, fine grained mortar, fineness, compressive strength, flexural strength

\begin{abstract}
This paper investigates the performance of rice husk ash (RHA) in a fine grained mortar. RHA produced from control combustion of rice husk. Fine grained mortar (FGM) is a mortar containing fine sand with a maximum size of $1 \mathrm{~mm}$. Chemical composition of RHA and Ordinary Portland Cement (OPC) were investigated using XRF in order to know the silica content in these materials. The particle size of RHA was analyzed to make sure it fineness is same with OPC after grinding. Compressive and flexural strength of FGM were tested on mortar prism for size $40 \mathrm{~mm} \mathrm{x}$ $40 \mathrm{~mm} \times 160 \mathrm{~mm}$ with replacement of RHA $10 \%, 20 \%$ and $30 \%$ by weight of cement at 7 days and 28 days of curing. All 24 specimens of FGM were caste and tested. The flexural strength, compressive strength of FGM have shown quite encouraging and interesting results. The optimum replacement of RHA in FGM from compressive and flexural strength is $20 \%$ by weight of cement.
\end{abstract}

\section{Introduction}

Utilization of agricultural waste material are required in the sustainable development of the concrete industry. Used of OPC as a binder in concrete become one of the reason the concrete are not sustainable. The production of Portland cement is a major contributor to greenhouse gasses with emission of carbon dioxide [1]. Some of the commonly agriculture waste material are RHA, palm oil fuel ash and bagasse ash. These wastes can be used as a supplementary cementing materials in concrete[1-4].

Rice husk is one of the waste material from agricultural industry. Rice husk is the outer shell of rice grain. Rice husk is generate from rice milling industries and it is known agro industrial by product in the world [16]. About 500 million tons of paddy are produced annually in the world. RHA is obtained from controlled and uncontrolled burning of rice husk. $100 \mathrm{~kg}$ of rice husk can produce about $20 \mathrm{~kg}$ of RHA. It is estimated around $20 \%$ of rice husk become RHA[1,5,6]. RHA recently become one of pozzolanic material. Pozzolanic material is a siliceous and aluminous material which in itself have little or no cementitious value, but will in finely divided with the presence of moisture. It will chemically react with calcium hydroxide at ordinary temperature during hydration of Portland cement [15]. RHA are contained about 80 to $95 \%$ silica, which is highly reactive in different temperature of incineration [6-8]. Numerous study to know the strength of concrete and mortar with optimum replacement level $10 \%$ to $30 \%$ of OPC by RHA $[4,5,8,9,10]$.

Fine grained mortar (FGM) is a combination of cement, fine sand and water. The specialty about FGM is using small maximum grain size of $1 \mathrm{~mm}$ [11-13]. Due to a very small diameter of grain size, it have possibility to get a new, very thin mortar and concrete element as application for the new material [14]. Most of the previous study [4,15] focusing on the replacement of pozzolanic material in mortar, a study on the need of pozzolanic material especially RHA in FGM is still lacking. FGM using fly ash as a partial replacement of OPC have been applied and it was identified that $20 \%$ replacement gives higher strength [12]. 


\section{Materials and Mix Proportions}

Materials. FGM is a special binder system which is achieved by using small maximum grain size of $1 \mathrm{~mm}$. FGM mixed are content of OPC, RHA, fine sand, water and superplasticizer. The cement used in this investigation consists of market available that is OPC. Fig.1 shows the production of RHA from rice husk until it becomes a powder. RHA produced from control combustion in $600^{\circ} \mathrm{C}$ temperature of rice husk collected from Muar, Malaysia. After the burning process, RHA was grounded for 5 minutes by using a ball mill grinder. This machine consist of rotating drum up and down with 12 steel balls in the drum for grinding. After grinding process, RHA in the form of powder was tested by using particle size analyzer to make sure RHA is $97 \%$ and above passing sieve $45 \mu \mathrm{m}$ same with OPC. Fig. 2 shows the particle distribution produces from particle size analysis for OPC and RHA. From fig. 2, it reveals that the fineness of RHA is same with OPC after 5 minute grinding processes and can be used in FGM.

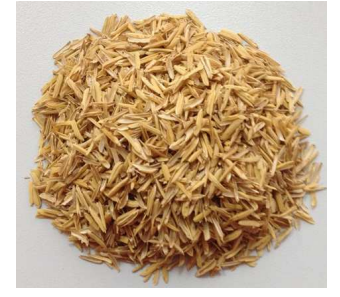

(a)

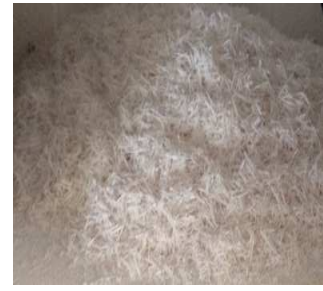

(b)

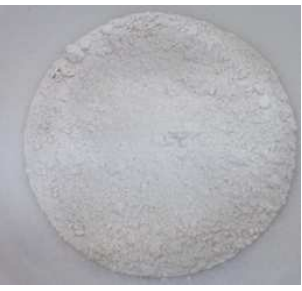

(c)

Fig.1, RHA production; (a) Rice husk, (b) Burnt RHA and (c) ground RHA.

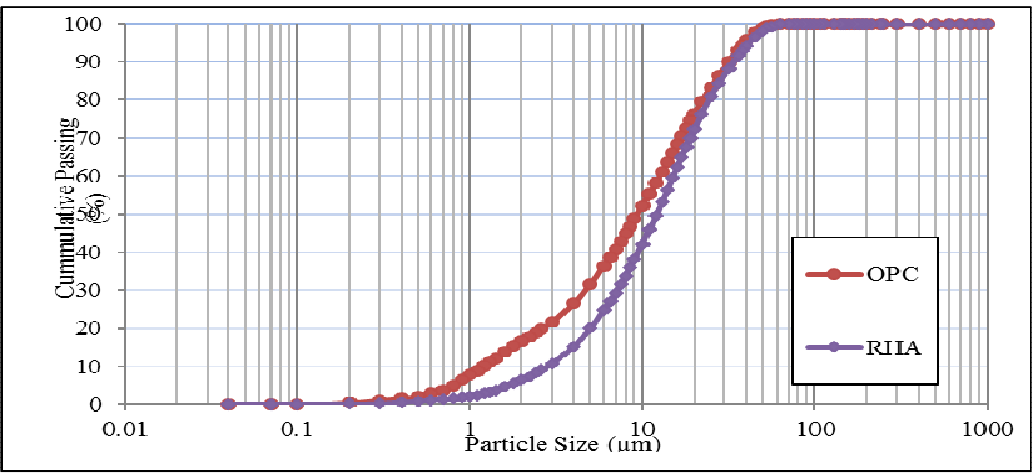

Fig. 2, Particle size distribution for OPC and RHA

The chemical composition of OPC and RHA as tabulated in table 1. From table 1 it can be seen that RHA have highly siliceous $\left(\mathrm{SiO}_{2} 96.00 \%\right)$ compared to OPC $\left(\mathrm{SiO}_{2} 16.40 \%\right)$.

Table 1. Chemical composition of OPC and RHA

\begin{tabular}{|c|c|c|}
\hline Chemical Composition & RHA (\%) & OPC (\%) \\
\hline $\mathrm{SiO}_{2}$ & 96.0 & 16.40 \\
\hline $\mathrm{Al}_{2} \mathrm{O}_{3}$ & 0.38 & 4.70 \\
\hline $\mathrm{Fe}_{2} \mathrm{O}_{3}$ & - & 3.70 \\
\hline $\mathrm{CaO}$ & 1.26 & 69.60 \\
\hline $\mathrm{MgO}$ & 0.47 & 1.22 \\
\hline $\mathrm{K}_{2} \mathrm{O}$ & 0.86 & 0.67 \\
\hline $\mathrm{SO}_{3}$ & 0.27 & 2.65 \\
\hline $\mathrm{LOI}$ & 4.0 & 2.2 \\
\hline
\end{tabular}

Mix Proportions. In this study, FGM mixed have been chosen with ratio 1:3 represented 1 for cement and 3 for fine sand. For cement ratio, cement is combined with different percent replacement of RHA. RHA replacement levels $0-30 \%$ by weight of cement are prepared. The 
water to binder ratio was kept constant at 0.5 . The superplasticizer content is $1 \%$ by weight of cement to maintain the workability of FGM. $40 \mathrm{~mm}$ x $40 \mathrm{~mm}$ x $160 \mathrm{~mm}$ prism moulds were used for casting. The FGM was left in the mould and allowed to set for 24 hours before the prism were de moulded and placed in the curing tank. FGM prism was cured in the curing tank for 7 and 28 days for flexural and compression test. FGM were prepared 3 samples for every percentage and days. The mix proportions of FGM for 3 samples are given in table 2.

Table 2. FGM Mix proportions

\begin{tabular}{|c|c|c|c|c|c|c|}
\hline No & Specimen & $\begin{array}{c}\text { Cement } \\
(\mathrm{g})\end{array}$ & RHA $(\mathrm{g})$ & $\begin{array}{c}\text { Fine sand } \\
(\mathrm{g})\end{array}$ & $\begin{array}{c}\text { Water binder } \\
\text { ratio }(\mathrm{ml})\end{array}$ & $\begin{array}{c}\text { Superplasticizer } \\
(\mathrm{ml})\end{array}$ \\
\hline 1 & Control & 150 & 0 & 450 & 75 & 1.5 \\
\hline 2 & RHA 10 & 135 & 15 & 450 & 75 & 1.35 \\
\hline 3 & RHA 20 & 120 & 30 & 450 & 75 & 1.2 \\
\hline 4 & RHA 30 & 105 & 45 & 450 & 75 & 1.05 \\
\hline
\end{tabular}

\section{Methods}

Flexural and Compressive Strength of FGM. Flexural strength of FGM was investigated using the Instron testing machine. The standard size of FGM specimen was $40 \mathrm{~mm}$ x $40 \mathrm{~mm}$ x $160 \mathrm{~mm}$. Test specimens were tested immediately after it is removed from water while they are still in wet condition. The flexural test was performed on three point loading system. Fig.3 shows Instron machine used to test the FGM specimen. For compressive strength test, the flexural testing specimen split into 2 parts were used. Fig.4 shows compressive testing machine used in this investigation.

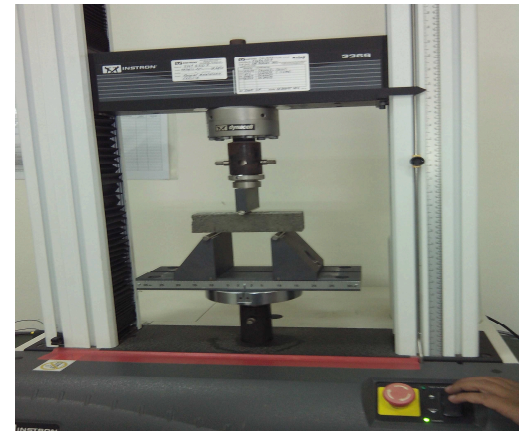

Fig.3, Instron machine for flexural testing

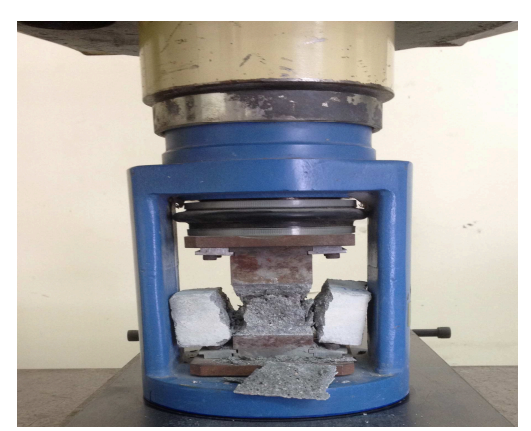

Fig. 4, Compressive testing machine

\section{Results and Discussion}

Flexural Strength of FGM. Table 3 shows the results of flexural testing of FGM. It is observed that the flexural strength of FGM was increased by $10 \%$ and $20 \%$ replacement compared to the control specimen. But in 30\% replacement, the flexural strength was decreased. The maximum flexural strength was obtained at $20 \%$ replacement of RHA with result $4.37 \mathrm{~N} / \mathrm{mm}^{2}$ at 7 days and $6.66 \mathrm{~N} / \mathrm{mm}^{2}$ for 28 days compared to control FGM. 
Table 3. Result of FGM flexural strength

\begin{tabular}{ccc}
\hline Specimen & $\begin{array}{c}\text { RHA replacement } \\
(\%)\end{array}$ & $\begin{array}{c}\text { Average flexural } \\
\text { strength }\left(\mathrm{N} / \mathrm{mm}^{2}\right)\end{array}$ \\
\hline 7 days & 0 & 3.59 \\
\cline { 2 - 3 } & 10 & 3.90 \\
\cline { 2 - 3 } 28 days & 20 & 4.37 \\
& 30 & 2.58 \\
\hline & 0 & 4.62 \\
\hline & 10 & 5.29 \\
\hline & 20 & 6.66 \\
\hline
\end{tabular}

Compressive Strength of FGM. The compressive strength development at 7 days and 28 days is given as in Table 4 . The result shows the compressive strength at 7 days were comparable except for $30 \%$ replacement. While at the age 28 days, FGM with $20 \%$ replacement shows higher in strength compared to control FGM with result $50.06 \mathrm{~N} / \mathrm{mm}^{2}$ for $20 \%$ RHA replacement FGM and 43.08 $\mathrm{N} / \mathrm{mm}^{2}$ for control FGM. This is due to the fineness and higher silica of RHA allowed to increased the reaction with $\mathrm{Ca}(\mathrm{OH})_{2}$ and produce more calcium silicate hydrate $(\mathrm{CSH})$ and contribute to the higher compressive strength in FGM [10]. It is also noticed that FGM with replacement of 10\% achieved slightly lower values of compressive strength because of the amount of RHA is not adequate to enhance the strength [10].

Table 4. Result of FGM compressive strength

\begin{tabular}{ccc}
\hline Specimen & $\begin{array}{c}\text { RHA replacement } \\
(\%)\end{array}$ & $\begin{array}{c}\text { Average } \\
\text { compressive } \\
\text { strength }\left(\mathrm{N} / \mathrm{mm}^{2}\right)\end{array}$ \\
\hline 7 days & 0 & 28.13 \\
\cline { 2 - 3 } & 10 & 26.42 \\
\cline { 2 - 3 } 28 days & 20 & 28.13 \\
& 30 & 17.08 \\
\cline { 2 - 3 } & 0 & 43.08 \\
\hline & 10 & 39.73 \\
\hline & 20 & 50.06 \\
\hline
\end{tabular}

\section{Conclusion}

RHA used in this study is efficient as a pozzolanic material because it contains higher in silica content $(96.00 \%)$ and its fineness are similar with OPC after grinding process in 5 minutes. RHA can be used as a partial cement replacement if FGM. The flexural and compressive strength of FGM with 20\% replacement RHA give an optimum strength. Use of high volume RHA in any construction work as a partial replacement of cement, provides a lower impact on the environment because it can reduce the production of cement. Other than that the amount of agricultural waste such as rice husk can be reduced by utilization in the concrete industry.

\section{Acknowledgements}

The support provided by Universiti Tun Hussein Onn Malaysia in the form of a research grant for this study is very much appreciated. The authors wish to acknowledge the technicians of Structure Engineering Laboratory and Material Laboratory, Faculty of Civil and Environmental Engineering for their help in carrying out the laboratory test. 


\section{References}

[1] A. Ramezanianpour, "The effect of rice husk ash on mechanical properties and durability of sustainable concretes," Int. J. ..., vol. 7, no. 2, pp. 83-91, 2009.

[2] M. U. Dabai, C. Muhammad, B. U. Bagudo, and A. Musa, "Studies on the Effect of Rice Husk Ash as Cement Admixture," vol. 17, pp. 252-256, 2009.

[3] W. Tangchirapat, C. Jaturapitakkul, and P. Chindaprasirt, "Use of palm oil fuel ash as a supplementary cementitious material for producing high-strength concrete," Constr. Build. Mater., vol. 23, no. 7, pp. 2641-2646, Jul. 2009.

[4] K. Ganesan, K. Rajagopal, and K. Thangavel, "Rice husk ash blended cement: Assessment of optimal level of replacement for strength and permeability properties of concrete," Constr. Build. Mater., vol. 22, no. 8, pp. 1675-1683, Aug. 2008.

[5] R. Kishore, V. Bhikshma, and P. J. Prakash, "Study on Strength Characteristics of High Strength Rice Husk Ash Concrete," Procedia Eng., vol. 14, pp. 2666-2672, Jan. 2011.

[6] G. Sivakumar and R. Ravibaskar, "Investigation on the hydration properties of the rice husk ash cement using FTIR and SEM,” Appl. Phys. Res., pp. 71-77, 2009.

[7] H. Chao-Lung, B. Le Anh-Tuan, and C. Chun-Tsun, "Effect of rice husk ash on the strength and durability characteristics of concrete," Constr. Build. Mater., vol. 25, no. 9, pp. 37683772, Sep. 2011.

[8] S. Rukzon, P. Chindaprasirt, and R. Mahachai, "Effect of grinding on chemical and physical properties of rice husk ash,” Int. J. Miner. Metall. Mater., vol. 16, no. 2, pp. 242-247, Apr. 2009.

[9] M. Jamil, a. B. M. a. Kaish, S. N. Raman, and M. F. M. Zain, "Pozzolanic contribution of rice husk ash in cementitious system," Constr. Build. Mater., vol. 47, pp. 588-593, Oct. 2013.

[10] G. A. Habeeb and H. Bin Mahmud, "Study on Properties of Rice Husk Ash and Its Use as Cement Replacement Material 3 . Experimental Work 2 . Scope of Work," vol. 13, no. 2, pp. 185-190, 2010.

[11] J. Hartig, U. Häußler-Combe, and K. Schicktanz, "Influence of bond properties on the tensile behaviour of Textile Reinforced Concrete," Cem. Concr. Compos., vol. 30, no. 10, pp. 898906, Nov. 2008.

[12] C. F. Christy and D. Tensing, "Effect of Class-F fly ash as partial replacement with cement and fine aggregate in mortar," vol. 17, no. April, pp. 140-144, 2010.

[13] R. Contamine, a. Si Larbi, and P. Hamelin, "Identifying the contributing mechanisms of textile reinforced concrete (TRC) in the case of shear repairing damaged and reinforced concrete beams," Eng. Struct., vol. 46, pp. 447-458, Jan. 2013.

[14] A. Brückner, R. Ortlepp, and M. Curbach, "Textile reinforced concrete for strengthening in bending and shear," Mater. Struct., pp. 741-748, 2006.

[15] B. Kondraivendhan, "Strength And Flow Behavior Of Rice Husk Ash," vol. 14, no. 3, pp. 405-416, 2013.

[16] Neville, A.M. Properties of concrete 5 th. ed. Pearson Education; 2011.

[17] Information on http://www.ricehuskash.com. 